\title{
Seedling Survival on Erosion Control Treatments in a Salt Desert Area ${ }^{1}$
}

\author{
ROSS W. WEIN ${ }^{2}$ AND NEIL E. WEST
}

Graduate Research Assistant and Associate Professor, Range Science Department, Utah State University, Logan.

\section{Highlight}

Counts of seeded crested wheatgrass (Agropyron cristatum) and volunteer species were made on gully plugs and contour furrows in the spring to determine emergence and in the summer to determine survival ratcs. Soil surface moisture was measured 2 and 7 days following summer rain storms. Many seedlings emerged in the spring in response to winter and early spring precipitation. This moisture was quickly depleted. The retention of moisture from summer storms determined the seedling survival pattern around the structures. Drowning was apparent in gully plug bottoms, while slopes of the structures retained little water during the storms. The combination of irregular rainfalls, high evaporation rates, and poor soil infiltration rates reduced the effectiveness of summer rains. Only at the high water line of the gully plug retention dam and at the bottom of the furrows was there enough soil moisture to bencfit seedlings.

Various mechanical land treatments in arid regions have proven effective to reduce runoff and to decrease sediment and water movement from treated sites. These treatments increase moisture storage in the soil for plant establishment and use. The few experiments which have been done on the value of rangeland gully plugs or gully checks made with earthfill dams, have focused on water and sediment retention, rather than on seedling establishment and forage production. It has been found, however, that vegetation is essential to stabilize the structure, especially the spillway (Peterson and Branson, 1962). In contrast to the few studies on gully plugs, there is much more information about furrows. The success of furrowed treatments, measured in water held or forage produced, appears to depend on the spacing and construction of furrows, as well as the soil type of the area.

${ }^{1}$ Journal Paper No. 1062, Utah Agricultural Experiment Station, Logan. Financial support of the Bureau of Reclamation and Bureau of Land Management, U. S. Dept. of the Interior is gratcfully acknowledged. Received September 5, 1970; accepted for publication January 4, 1971.

${ }^{2}$ Presently Post-Doctoral Fellow, Department of Botany, University of Alberta, Edmonton, Alberta.
For either of these erosion control structures the establishment of plants on the structures is essential not only for stabilizing the soil but also for increasing the primary productivity of the area. Native species may invade successfully in some plant communities but reseeding may be needed at harsh sites.

Reseeding of the salt desert shrub ranges of the western United States has not been very successful, even though there was often good seedling emergence and early establishment (Bleak et al., 1965; Hull, 1963; Plummer et al., 1955; Valentine, Cook, and Stoddart, 1963). Bleak et al., (1965) believed that, in general, these failures were primarily caused by periodically prolonged or severe droughts. High salinity levels of the subsoil in these salt desert shrub areas accentuate the effects of low rainfall (Hull, 1962).

Some reseedings with desert wheatgrass (Agropyron desertorum) and crested wheatgrass (Agropyron cristatum) on furrowed nuttall saltbush areas have given good yields of the seeded species but the native species have not always showed increases (Branson et al., 1962; Nichols, 1964).

Most, if not all, of the researchers that measured plant establishment and plant yields on trcated areas believed that any increase in yield resulted from increased water retention and infiltration. Deep moisture storage has been measured by Dickenson et al. (1940), Hancock (1968), and Winkworth (1963) but the shallow moisture storage essential to seedling establishment has been examined only slightly. Winkworth (1963) found that the top inch of soil dried very quickly after the rain ceased at a sandy soil site in Australia.

The purpose of this study was to examine seedling emergence and soil moisture following summer rains to: (I) determine the contribution of these rains to the survival of seedlings established in the spring, and (2) to predict on what part of the erosion-control structures plants would persist.

\section{Study Areas and Procedurc}

The two study areas are locatcd in the Grand River Valley of southeastern Utah near the village of Cisco. Washes drain the study areas toward the Colorado River, which is approximately $15 \mathrm{~km}$ (9 miles) to the southeast. The areas are much dissected by arroyos and the vegetal cover is approximately 2 to 4 percent.

Soil-vegetation relationships have been reported by West and Ibrahim (1968). Two of the habitat types described by these workers were included in the present study: Nuttall saltbush-galleta grass (Atriplex nuttallii var. nuttallii-Hilaria jamesii) and mat saltbush (Atriplex corrugata). ${ }^{3}$

The soil profile of the Nuttall saltbush habitat type is loamy, nonalkaline throughout, but saline below $38 \mathrm{~cm}$ (15 inches). The profile of the mat saltbush habitat type is heavy textured and saline-alkaline throughout.

The climate in southeastern Utah is arid. U. S. Weather Bureau records show $16.23 \mathrm{~cm}$ (6.39 inches) average annual precipitation at Cisco, Utah for the period 19531966. Peak precipitation is received in October, with secondary peaks in January and April. Summer rainfall is low and results from a few high intensity localized thun-

${ }^{3}$ Taxonomic nomenclature follows Harrington (1964). 


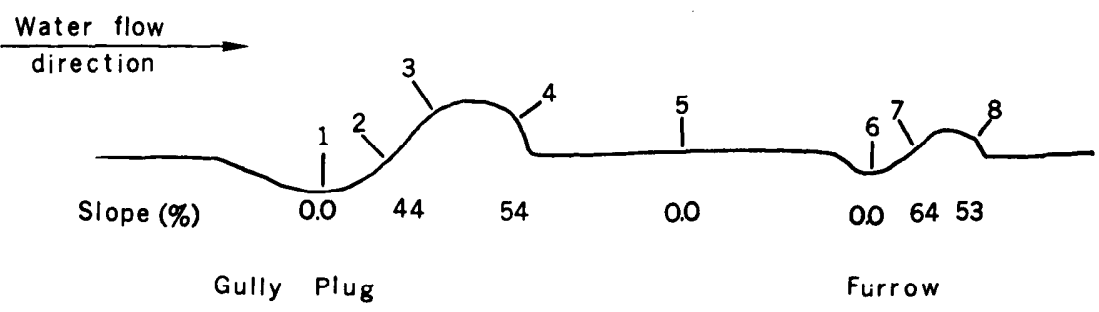

Fic. 1. Cross section of erosion control structures indicating position designations and corresponding slopes on the gully plug (1-4), contour furrow (6-8) and untreated microtopography of the control (5).

derstorms. From weather data recorded by instruments within 1 kilometer of the study areas, it was found that rain fell on 19, 16, and 18 days from mid-April to midOctober of 1966, 1967, and 1968, respectively. Five of these days each year received one-half centimeter or more rain.

Soil crosion control treatments consisting of gully plugs and contour furrows were installed on the mat saltbush area in 1962, while the other area was treated 2 years later. The gully plugs in the Nuttall saltbush area averaged $9.1 \mathrm{~m}(30 \mathrm{ft}$ ) in diameter and $0.9 \mathrm{~m}(3 \mathrm{ft})$ deep. The gully plug density was 4.2 /hectare (1.7/acre). On the mat saltbush area, the gully plugs averaged $6.4 \mathrm{~m}$ $(21 \mathrm{ft})$ in diameter by $4.6 \mathrm{~m}(15 \mathrm{ft})$ wide. The density was $8.9 /$ hectare (3.6/acre). Furrows were $30 \mathrm{~cm} \mathrm{(12}$ inches) deep and $46 \mathrm{~cm}$ (18 inches) wide when constructed, but now are approximatcly $15 \mathrm{~cm}$ (6 inches) deep. Twelve to sixteen percent of the area was disturbed.

In the early spring of 1967 a study was set up to determine seedling emergence, growth and survival responses to the microclimate of the erosion control structures in the Nuttall and mat saltbush areas. It was hoped that seedlings could be established in plastic lined metal cans, and then the cans could be placed in differing microreliefs of the structures. It was found, however, that evaporation was too great to obtain satisfactory seedling growth.

At this point it was decided to seed crested wheatgrass, Fairway strain, directly on the structures. Treatments consisted of 5 replications of east, south, and west aspects within each area. Each aspect within a replication consisted of a gully plug and an adjacent furrow. Position designations are shown in cross-sectional Figure 1. Seed with 82 percent viability was sown at the in a band one meter wide through the gully plug, starting at the water retention area (position 1) and continuing over the throw (position 4). A two meter length of the adjacent furrow also was sown. This seeding was carried out before the rains in the spring of 1967, and then again in October of 1967. The seed was raked into the soil with a garden rake to improve chances of germination.

Seeded grass and volunteer seedlings were counted under a subsampling frame 50 by $100 \mathrm{~cm}$, equipped with cross strings to facilitate counting. Two subplots were taken at each of the eight positions. In positions 1 to 5 , the subplots were taken side by side, forming a whole plot 1 by $1 \mathrm{~m}$. In positions 6 to 8 , the subplots were taken end to end, forming a whole plot 0.5 by $2.0 \mathrm{~m}$.

Since there were no early spring rains in 1967, counts were taken to determine the survival rate during the fourth week of July after the summer rains, and again during the fourth week of September. In 1968, readings were taken during the second week of April, and then again during the first week of July, when the seedlings appeared to be dying. Spring counts were taken when the grass seedlings were 1 to $6 \mathrm{~cm}$ tall. Count data were transformed by the square root transformation before analyzing them statistically. rate of $8.1 \mathrm{~kg} /$ hectare $(8 \mathrm{lb}$ /acre)
To study the rate at which water is depleted from the microsites in the gully plugs and furrows, soil moisture samples were gathered 2 and 7 days after rains in the two habitat types. Data were taken after $1.9 \mathrm{~cm}$ and $3.2 \mathrm{~cm}$ rains in the Nuttall saltbush area, and after $0.8 \mathrm{~cm}$ and $2.5 \mathrm{~cm}$ rains in the mat saltbush area during August of 1967 and 1968.

Four replications of three aspects of the eight positions shown in Figure 1 were chosen in each area. At these eight positions, a composite sample of three subsamples was dug with a soil auger at $0-5,5-10$, and 10-15 cm depths. The composite sample was placed in a metal soil can and dried at $105 \mathrm{C}$ for 24 hours to determine percent moisture on a dry weight basis. Bulk density samples were obtained with a $100 \mathrm{~cm}^{3}$ soil core sampler, which was tapped into the soil with a mallet. The bulk density was used to convert the percent moisture by weight to percent moisture by volume.

An analysis of variance was done for each area separately because of differing amounts of rainfall. All seedling establishment and soil surface moisture results given below are statistically significant.

\section{Results}

Seedling counts presented in Table 1 show that grass seedings were not evenly distributed over erosion control structures for all seasons. The highest concentration of grass seedlings was found at the gully plug high water line (position 2 ) and contour furrow bottom (position 6) for all periods observed. Position 1 had lower values than position 2. Introduced grasses would most likely establish in positions 2 and 6 in a wet year but no establishment could be expected at the top of gully plug throw.

The habitat type means interacted with position and time. These data indicated similar low values for the spring and summer of 1967 and for the summer of 1968. In the spring of 1968, however, only at positions 3 and 4 were the 
Table 1. Grass seedling (G) and volunteer seedling (V) counts per square meter for spring and summers of 1967 and 1968 at eight positions on the structures. See Figure 1 for key to positions on the erosion control structures.

\begin{tabular}{|c|c|c|c|c|c|c|c|c|c|}
\hline \multirow[b]{2}{*}{ Year and season } & \multirow{2}{*}{$\begin{array}{l}\text { Kind of } \\
\text { seedling }\end{array}$} & \multicolumn{8}{|c|}{ Positions on structures } \\
\hline & & 1 & 2 & 3 & 4 & 5 & 6 & 7 & 8 \\
\hline \multicolumn{10}{|l|}{1967} \\
\hline \multirow[t]{2}{*}{ Spring } & $\mathbf{G}^{1}$ & 0 & 2 & 0 & 0 & 0 & 0 & 0 & 0 \\
\hline & $\mathrm{V}^{2}$ & 6 & 20 & 28 & 2 & 10 & 24 & 24 & 18 \\
\hline \multirow[t]{2}{*}{ Summer } & G & 0 & 8 & 0 & 0 & 2 & 8 & 2 & 0 \\
\hline & $\mathrm{V}$ & 4 & 8 & 4 & () & 12 & 6 & 4 & 4 \\
\hline \multicolumn{10}{|l|}{1968} \\
\hline \multirow[t]{2}{*}{ Spring } & G & 58 & 76 & 6 & 0 & 44 & 126 & 38 & 24 \\
\hline & $\mathrm{V}$ & 74 & 374 & 70 & 10 & 130 & 104 & 92 & 100 \\
\hline \multirow[t]{2}{*}{ Summer } & G & 10 & 22 & 0 & 0 & 8 & 36 & 12 & 10 \\
\hline & V & 32 & 158 & 48 & 22 & 136 & 82 & 98 & 114 \\
\hline
\end{tabular}

$195 \%$ confidence limits for grass seedling means are $\overline{\mathrm{X}} \pm 1$.

${ }^{2} 95 \%$ confidence limits for volunteer seedling means are $\bar{X} \pm 1$.

counts similar in the two habitat types. At the other positions, more seedlings were present in the Nuttall saltbush area. The maximum difference occurred at position 6 where the counts were 160 and 92 per $\mathrm{m}^{2}$ for the Nuttall and mat saltbush habitat types, respectively.

In addition to the information given in Table 1 the season $\times$ aspect $x$ habitat type interaction showed that almost no grass seedlings emerged in the spring of 1967, but more emerged before the summer count. This lack of grass seedling emergence resulted from the absence of snow after December 1966 and lack of rain in the spring of 1967. In the spring of 1968 , counts reached 54 seedlings per $\mathrm{m}^{2}$ in the Nuttall saltbush area and 38 seedlings per $\mathrm{m}^{2}$ in the mat saltbush area. The differences between aspects may have resulted from several factors, including differences in salinity levels of the soil and/or differences in moisture distribution caused by wind patterns during rainstorms.

The aspect $\times$ position interaction resulted mainly from differing seedling counts at positions 2 and 6 . Position 2 had higher values for the east aspect. At position 6 the south aspect has the highest counts, while the west aspect had the lowest. These results may be directly related to the drainage basin characteristics.
Volunteer seedlings did not include the same species in both areas. In the Nuttall saltbush area, the volunteers were Halogeton ( $\mathrm{Hal}$ ogeton glomeratus), Russianthistle (Salsola kali), Eriogonum inflatum, and $E$. salsuginosum, in descending order of density. In the mat saltbush area the volunteers were Malcomia africana, Russianthistle, rabbitbrush (Chrysothamnus viscidiflorus), Eriogonum inflatum, $E$. salsuginosum, and a very few cheat grass (Bromus tectorum), in descending order of density.

The season $\times$ position interaction data showed a greater stand of volunteer seedlings in 1968 than in 1967, and the spring values were generally higher than the summer values (Table 1). Greatest survival in the summer of 1967 occurred at positions 2 and 5 , and in 1968 at positions 2, 5, 6, 7, and 8 .

Habitat type interacted with position and season. In 1967 mean counts for both habitat types were similarly low (below 40 per $\mathrm{m}^{2}$ ) for both spring and summer. In 1968 there were usually more volunteer forbs in the mat saltbush habitat type, especially at positions 1, 2, 7, and 8 . Almost all seedlings drowned at position 1 of the Nuttall saltbush habitat type. At position 2, counts in the mat saltbush habitat type were about 50 seedlings higher, while at position 7 and 8 they were about 25 seedlings per $\mathrm{m}^{2}$ higher.
It was noted in the summer of 1968 that seeds from indigenous species had established on the structures. The number of Nuttall saltbush seedlings per square meter averaged over replications and aspects was $0.0,1.6,0.1,0.0,3.6,0.8$, 0.5 , and 1.1 at positions 1 through 8 , respectively. In the mat saltbush habitat type, the seedling counts of this species were $3.1,2.0,1.8,1.9$, $6.7,1.2,1.8$, and 1.7 for positions 1 through 8 , respectively. In this habitat type, nonuniform dispersal of seeds may have accounted for the high numbers at position 5 and the lower numbers at positions 2, 3, 4, 6, 7, and 8. Positions 3 and 4 had high values considering the harsh environment of these establishment sites. Position 1 in the Nuttall saltbush habitat type was apparently a much harsher site for seedling establishment than in the other area, although this position should have had large numbers of seeds carried by runoff water.

Soil surface moisture retention data for the position $\times$ season interaction is shown in Table 2. In the Nuttall saltbush habitat type, the highest values were found in the gully plug bottoms with moderate amounts at the gully plug water line and contour furrow bottom. The moisture percentages obtained 2 days after the rainstorms were usually higher than 5 days later, but the differences were often small. At position 1, however, the moisture value taken 7 days after the heavy rainfall was higher. This resulted, first because this position was flooded when both sets of samples were taken making sampling difficult. Secondly, as the depth means at position 1 show, water moved into the soil and raised the moisture content of the 5-10 and $10-15 \mathrm{~cm}$ samples by the second sampling period. The depth means were very similar for positions 3,4 , 5,7 , and 8 at all times.

In the mat saltbush habitat type the results were very similar to those in the Nuttall saltbush arca. In addition, the season $\times$ aspect interaction indicated that the soil around the structures with a western aspect held more moisture than 
Table 2. Soil moisture (\% by volume) two and seven days after rains. The values for the eight positions are given for the two habitat types separately. See Figure 1 for the key to positions on the erosion control structures.

\begin{tabular}{ccrrrrrrrr}
\hline \hline $\begin{array}{c}\text { Amount of } \\
\text { precip. (cm) }\end{array}$ & $\begin{array}{c}\text { Days after } \\
\text { storm }\end{array}$ & 1 & 2 & 3 & 4 & 5 & 6 & 7 & 8 \\
\hline $\begin{array}{c}\text { Nuttall saltbush } \\
\text { habitat type }\end{array}$ & & & & & & & & & \\
1.9 & 2 & 47.0 & 25.2 & 9.8 & 7.6 & 12.3 & 22.4 & 13.4 & 9.7 \\
& 7 & 19.4 & 11.8 & 7.5 & 5.2 & 7.9 & 10.5 & 7.4 & 6.4 \\
3.2 & 2 & 57.5 & 29.5 & 6.7 & 6.5 & 6.4 & 21.6 & 11.4 & 8.2 \\
& 7 & 64.9 & 20.5 & 5.2 & 5.6 & 6.8 & 14.5 & 7.5 & 6.4 \\
Mat saltbush & & & & & & & & & \\
habitat typc & & & & & & & & & \\
0.3 & 2 & 20.9 & 15.4 & 12.9 & 12.2 & 13.8 & 18.5 & 13.2 & 12.6 \\
& 7 & 10.9 & 6.9 & 6.3 & 5.6 & 6.8 & 10.0 & 6.0 & 5.8 \\
2.5 & 2 & 60.5 & 29.4 & 9.4 & 7.6 & 7.8 & 31.3 & 12.9 & 9.0 \\
& 7 & 19.4 & 16.6 & 5.8 & 4.8 & 5.8 & 14.7 & 6.4 & 5.2 \\
\hline
\end{tabular}

${ }^{1} 95 \%$ confidence limits for moisture means are $\bar{X} \pm 2.2$.

$295 \%$ confidence limits for moisture means are $\bar{X} \pm 1.2$.

other exposures 2 days after the rain but less 7 days after the rain. This could have been caused by slightly larger watersheds and a slightly greater infiltration capacity around the erosion control structures.

Other interactions showed that the surface soil at position 1 had the highest water content. The surface soil at all other positions had lower values and therefore was a less favorable environment for seedling establishment. The $5-10 \mathrm{~cm}$ level was wettest at all positions because water that penetrated to this depth remained longer. The $10-15 \mathrm{~cm}$ depth usually received less moisture following rainstorms than the 5-10 cm depth because of the low permeability of the soil. This was especially true at positions $3,4,5,7$, and 8 .

Aspect interacted with the position $\times$ depth interaction. At positions $3,4,5,7$, and 8 the west aspect had higher values for all depths, possibly as a result of a better structured or coarser textured soil. The east aspect usually had lower values. In contrast, at positions 2 and 6 , the east aspect tended to have more moisture, while at position 1 thc east and south aspects both had higher moisture levels than the west aspect. This indicated that the structures on the east and south aspects had less infiltration and more runoff than the structures on the west aspect.

\section{Discussion}

The seedling trials show that these salt desert areas have a harsh environment that prevents the survival of many plant seedlings. The gully and furrows, however, have modified the microenvironment to the extent that some microsites are favorable for establishment. It remains to be seen how well these established plants will survive periodically prolonged or severe droughts such as discussed by Bleak et al. (1965).

The emergence of a few saltbush seedlings in the spring of 1968 showed that there were viable seeds of indigenous species in the soil and that these species could invade the erosion control structures in time. Although seed from perennial indigenous species was probably moved into the gully plugs and furrows by runoff water, there was no large count of seedlings in these positions. This could have resulted from inhibitory substances in the bracts as described by Vest and Cottam (1953), the lack of viablc seeds, or the drowning of young seedlings.

Seedlings that emerge in the spring rely on the soil moisture stored during late fall rains or early spring snowmelt water that infiltrates into the soil. Precipitation received from early November to the end of March in 1967 was about $4 \mathrm{~cm}$ but in $1968 \mathrm{it}$ was about $9 \mathrm{~cm}$. This latter level of precipitation was sufficient for the germination of many seeds.

Volunteer seedlings emerged in greater numbers and provided competition for the introduced grass. Spring seedling counts of grass in 1968, were sufficient for a good stand at any aspect or position with the possible exception of the outside of the gully plug throw. This agrees with the findings of Bleak et al. (1965) and others that good seedling stands are not unusual in salt desert areas.

There was a difference in seedling emergence and survival between habitat types. Grass seedlings were in higher numbers in the Nuttall salıbush habitat type, where as in the mat saltbush area the volunteer seedlings had an advantage. This difference could have been the result of the difference in salinity between the two areas (West and Ibrahim, 1968; R. W. Wein, unpublished data).

On top of this edaphic factor, that limited plant development, there was also a hostile microclimatic environment. Small amounts of moisture were quickly lost in this arid environment. Soil water held between $1 / 3$ and 15 atmospheres tension was lost from miniature lysimeters at rates of 4.4, 4.5, 6.7, $4.8 \mathrm{~mm}$ per day for the periods of April 30-May 4, May 14-21, June 19-23, and July 19-23, respectively (R. W. Wein, unpublished data). This would indicate that even winter moisture storage was quickly depleted early in the growing season. Summer moisture was depleted in a shorter time.

These high evaporation rates also help explain the reason for the failure of seedling survival in the containers used for the pilot study initiated in the spring of 1967. The soil in the containers was exposed to the very dry winds which dried the upper part of the soil where the seedlings were growing. 
The seedling survival values were very closely connected with the soil moisture values found after summer rains.

In the bottom of the gully plugs, there were similar numbers of grass and volunteer seedlings but total numbers were lower than at other positions. The seedlings in the gully plug bottom emerged only from cracks in the clay, where the environment was apparently not as harsh. Seedlings in this position were often covered or coated with clay following water evaporation after rains. As water evaporated from position 1 , the transported material from the last storm dried, breaking horizontally along the level of the coarser material that settled out first, and then breaking vertically into crudely shaped polygons. This caused seedlings to become uprooted or, more commonly, broken off. Transported sediment to this position has been 5.71 and $1.31 \mathrm{~cm}$ per year in the Nuttall and mat saltbush areas, respectively (D. B. Thomas, unpublished data).

The other obvious factor in limiting seedling establishment in the gully plugs catchment basin was that of drowning. This was especially true in the Nuttall saltbush area where the drainage basins were much larger. If the soil had been of coarser texture, infiltration and storage would have been greater but the fine material transported to this position tended to reduce infiltration. Infiltration rates of 0.3 $\mathrm{mm} /$ hour were measured in the Nuttall saltbush area in the gully plug catchment basin. Evaporation from this position appears to be comparable to the pan evaporation rates measured by the U.S. Weather Bureau at Green River, Utah. An average evaporation rate of $7.5 \mathrm{~mm} /$ day was measured for June 1968.

The gully plug catchment basin contrasts with the very dry sites of the control and the gully plug and furrow throw positions. Just 2 days following the rainstorm the soil moisture was at or below the permanent wilting percentagc. This showed that the slopes of the erosion control structures tended to prevent infiltration, even though the shale material brought to the surface was highly structured. Small rills that indicated overland flow were found on some of these slopes.

The most successful establishment of seedlings was at the high water line of the gully plugs and in the contour furrow bottom. Water did not stay on the surface for more than 2 days so there was little drowning effect. At this time the soil was at approximately field capacity. By the seventh day following a storm, the soil moisture level was approaching the 15 atmosphere percentage.

Recording rain gauge data indicated up to three rainstorms per month during the summer. If runoff occurred in most storms, seedlings could receive somewhat more regular moisture in positions 2 and 6 than at other positions. Long term precipitation records show that $6.97 \mathrm{~cm}$ of the total average annual $16.23 \mathrm{~cm}$ falls from April to September, with two-thirds of the former received during April, May, and September in approximately equal amounts.

These counts of establishing seedlings bore out the visual observations of crested wheatgrass survival since control treatments were constructed and then seeded. These plants were generally found at positions 2 and 6 in the Nuttall saltbush habitat type. There were almost no mature crested wheatgrass plants in the mat saltbush habitat type because of the edaphic characteristics. Perennial vegetation such as crested wheatgrass, even if it required much more soil moisture than the indigenous shrubs, could grow well in position 2. Some roots would penetrate into the soil below the gully plug catchment basin to use the moisture, yet not suffer from drowning effects.

Since microsites now range in harshness from those favorable to plant growth to very harsh sites on the throws of the structures where only short lived annuals may grow, invasion of this salt desert area by other spccics is inevitable.

There is evidence that water tables do exist in some of the older gully plug treatments around Cisco.
Two plants that are thriving and which usually indicate ground water storage are tamarix (Tamarix pentandra) and greasewood (Sarcobatus vermiculatus). Rabbitbrush and reed (Phragmites communis) have also been observed growing in older gully plugs.

In view of this summer soil surface moisture data, it is doubtful if the gully plugs will contribute greatly to increasing foragc or covcr. The narrow band of perennial plants that can be suported near the high water line of the gully plug is not sufficient to prevent erosion if rainfall runoff is grcater than the capacity of the structure.

The authors concur with Branson, et al. (1962 and 1966) and Nichols (1964), that furrows will be of greater value in increasing forage since the water does not stand in the furrows long enough to drown the plants.

\section{Literature Cited}

Barnes, O. K., D. Anderson, And A. Heerwagen. 1958. Pitting for range improvement in the Great Plains and the southwest desert regions. U.S. Dep. Agr. Production Res. Report 23. 17 p.

Bennett, H. H. 1955. Elements of soil conservation. 2nd ed. McGrawHill Book Co., Inc., New York. 358 p.

Bleak, A. T., N. G. Frischinecht, A. P. Plummer, and R. E. Eckert, Jr. 1965. Problems in artificial and nat ural revegetation of the arid shadscale vegetation zone of Utah and Nevada. J. Range Manage. 18:59-65.

Branson, F. A., R. F. Miller, and I. S. McQueEN. 1962. Effects of contour furrowing, grazing intensities and soils on infiltration rates, soil moisture and vegetation near Fort Peck, Montana. J. Range Manage. 15:151158.

Branson, F. A., R. F. Miller, and I. S. McQueEn. 1966. Contour furrowing, pitting, and ripping on rangelands of the western United States. J. Range Manage. 19:182-190.

Dickenson, R. E., B. C. Langley, And C. E. Fisher. 1940. Water and soil conservation experiments at Spur, Texas. Texas Agr. Exp. Sta. Bull. 587. $67 \mathrm{p}$.

Hancock, V. E. 1968. Effects of certain soil surface treatments on the 
soil moisture regime in the Cisco Basin, Utah. MS thesis, Utah State Univ., Logan, Utah.

HaRringtoN, H. D. 1964. Manual of the plants of Colorado. Sage Books, Denver, Colorado. 666 p.

Hull, A. C., JR. 1962. Growth in the greenhouse of grasses and shrubs on soils from shadscale and sagebrush areas. J. Range Manage. 15: 262-266.

Hull, A. C., JR. 1963. Seeding saltdesert shrub ranges in western Wyoming. J. Range Manage. 16:253-258.

Nichols, J. T. 1964. Cover, composition, and production of contour- furrowed and seeded range as compared to native saltsage range. Wyo. Range Manage. 187:26-38.

Peterson, H. V., and F. A. Branson. 1962. Effects of land treatments on erosion and vegetation on rangelands in parts of Arizona and New Mexico. J. Range Manage. 15:220-226.

Plummer, A. P., A. G. Hull, JR., G. STEWART, AND J. H. RoberTSON. 1966. Seeding rangelands in Utah, Nevada, southern Idaho, and western Wyoming. U. S. Dep. Agr., Forest Service Handbook 71. 73 p.

Vallentine, J. F., C. W. Cook, and L. A. StOdDart. 1963. Range seeding in Utah. Utah State Univ. Agr. Exp. Sta. Bull. 307. 20 p.

Vest, E. D., and W. P. Cottam. 1953. Some germination characteristics of Atriplex confertifolia. Utah Acad. Sci., Arts and Letters Proc. 30:108109.

Winkworth, R. E. 1963. Some effects of furrow spacing and depth on soil moisture in central Australia. J. Range Managc. 16:138-142.

WFst, N. F.., AND K. I. IbRAhim. 1968. Soil-vegetation relationships in shadscale zone of southeastern Utah. Ecology 49:445-456. 